\title{
Investigations on the shale oil and gas potential of Westphalian mudstone successions in the Campine Basin, NE Belgium (well KB174): Palaeoenvironmental and palaeogeographical controls
}

\author{
Wim VANDEWIJNGAERDE ${ }^{*}$, Kris PIESSENS ${ }^{2}$, Michiel DUSAR $^{2}$, Pieter BERTIER ${ }^{3}$, Bernhard M. KROOSS ${ }^{4}$, \\ RALF LITTKE ${ }^{4} \&$ RUDY SWENNEN ${ }^{1}$
}

\author{
${ }^{1}$ Earth and Environmental Sciences, KU Leuven, Celestijnenlaan 200E, 3001 Leuven, Belgium. \\ ${ }^{2}$ Geological Survey of Belgium, Royal Belgian Institute of Natural Sciences, Jennerstraat 13, 1000 Brussels, Belgium. \\ ${ }^{3}$ Clay and Interface Mineralogy, RWTH Aachen, Bunsenstrasse 8, 52056 Aachen, Germany. \\ ${ }^{4}$ Institute of Geology and Geochemistry of Petroleum and Coal, Energy and Mineral Resources (EMR), RWTH Aachen, \\ Lochnerstrasse 4 - 20, 52056 Aachen, Germany. \\ * corresponding author: wim.vandewijngaerde@kuleuven.be
}

\begin{abstract}
Westphalian mudstones in the Hechtel-Hoef well, Campine Basin, Belgium, were examined for their hydrocarbon potential by means of Rock-Eval pyrolysis. These mudstones have an average TOC content of 3.6\% and mean S2 and Hydrogen Index values of respectively 7.9 and $164.2 \mathrm{mg} / \mathrm{g}$ and contain a mixture of kerogen types II and III. This indicates that in contrast to the Westphalian coal seams, these successions are not predominantly gas-prone but could also generate higher molecular-weight hydrocarbons and condensates. Three different palaeoenvironments, i.e. non-marine flood plains (FP), freshwater palaeoenvironment $(\mathrm{FW})$, euryhaline palaeoenvironment $(\mathrm{E})$ were recognised in the Westphalian mudstones, each with different hydrocarbon potential. Flood plain environments show the highest TOC and S2 values. Mudstone intervals with high TOC content occur more frequently in Westphalian A and have in general higher S2 values. The higher abundance of kerogen type II-enriched organic matter in Westphalian A indicates a lower delta plain setting. It is shown that the palaeogeographic context can be used as a proxy for the hydrocarbon generation potential of mudstone deposits from the coastal plain or of lacustrine origin.
\end{abstract}

KEYWORDS: Carboniferous, hydrocarbon potential, palaeoenvironment, kerogen type

\section{Introduction}

European conventional natural gas reserves are depleting, which results in declining production curves. Consequently EU will become more dependent on the import of oil and gas than it is today (Söderbergh et al., 2009, 2010). On the other hand shale gas has become an important source of natural gas in the United States, feeding the economy, creating domestic jobs and improving the US energy balance. It is expected that the United States will be a net exporter of natural gas by 2030 (Paltsev et al., 2011: Manning, 2014). As a consequence, other countries in the world become interested in the domestic potential of unconventional oil and gas resources.

Estimates for Europe's technically recoverable shale gas volumes range between 3 and 18 trillion $\mathrm{m}^{3}(\mathrm{Tcm})$ (Weijermars, 2013) as compared to estimated world resources of $425 \mathrm{Tcm}$. The range reflects the inherent uncertainties of the estimates. Exploration is in progress in different EU Member States (e.g. United Kingdom, Poland, Hungary, Romania), or is taken into consideration (e.g. The Netherlands, Austria, Lithuania). These campaigns focused on marine black shales (Gasparik et al., 2012; Sachsenhofer \& Koltun, 2012; Uffman et al., 2012; Andrews, 2013), following their success in the United States.

The corresponding exploration target in Belgium is constrained to the Namurian aged Chokier Formation (Dusar, 2006; Nyhuis et al., 2014) (Fig. 1). The shale gas potential of the Namurian in the Campine Basin is poorly known, though the basin was explored for coal bed methane (Wenselaers et al., 1996; Van Tongeren et al., 2000; Van Tongeren \& Laenen, 2001; Ferket \& Laenen, 2008).

In comparison to the widespread international focus on marine black shales, research of continental deposits was rather uncommon. Nonetheless, recently a lot of research on this topic has been performed (Ding et al. 2013; Guo et al., 2014; Ji et al., 2014; Tang et al., 2014; Wang et al., 2015; Yang et al., 2015). The study presented here will evaluate the source rock potential and hydrocarbon composition of mud rock sequences (shale beds) directly overlying the Westphalian coal seams. These deposits, reaching an average thickness of one meter, are defined as roof shales, which were deposited during the transgressive phase of a cyclothem,

\begin{tabular}{|c|c|c|c|c|c|c|}
\hline System & $\begin{array}{c}\text { Series } \\
N W \\
\text { Europe }\end{array}$ & \multicolumn{2}{|c|}{$\begin{array}{l}\text { Stage } \\
N W \\
\text { Europe }\end{array}$} & $\begin{array}{c}\text { Series } \\
\text { ICS }\end{array}$ & $\begin{array}{l}\text { Stage } \\
\text { ICS }\end{array}$ & $\begin{array}{l}\text { Age } \\
\mathrm{Ma}\end{array}$ \\
\hline Permian & & & & & & Younger \\
\hline \multirow{7}{*}{ Carboniferous } & \multirow{5}{*}{ Silesian } & \multicolumn{2}{|c|}{ Stephanian } & \multirow{4}{*}{ Pennsylvanian } & Gzhelian & $\begin{array}{l}298.9- \\
303.7\end{array}$ \\
\hline & & \multirow{3}{*}{ 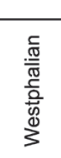 } & & & Kasimovian & $\begin{array}{l}303.7- \\
307.0\end{array}$ \\
\hline & & & $\frac{C}{B}$ & & Moscovian & $\begin{array}{l}307.0- \\
315.2\end{array}$ \\
\hline & & & A & & Bashirian & $315.2-$ \\
\hline & & \multicolumn{2}{|c|}{ Namurian } & \multirow{3}{*}{ Mississippian } & Serpukhovian & $\begin{array}{l}323.2- \\
330.9\end{array}$ \\
\hline & \multirow{2}{*}{ Dinantian } & \multicolumn{2}{|c|}{ Visean } & & Visean & $\begin{array}{l}330.9- \\
346.7\end{array}$ \\
\hline & & \multicolumn{2}{|c|}{ Tournaisian } & & Tournaisian & $\begin{array}{l}346.7- \\
358.9\end{array}$ \\
\hline Devonian & & & & & & Older \\
\hline
\end{tabular}

Figure 1. Comparison of regional NW European and international stratigraphy (Delmer et al., 2001; Dusar, 2006; Gradstein et al., 2012).

resulting in bituminous-rich shales with marine influences. The presence of coal seams had an important influence on the diagenesis of the shales, due to the release of carbon dioxide and organic acids during coalification (Van Keer et al., 1998a). Kerogen type and organic matter content in such brackish and lacustrine mudstones also differ from marine settings (Vandenberghe et al., 1988; Ross \& Bustin, 2009). Preliminary results indicate that these intervals show some hydrocarbon potential (Vandewijngaerde et al., 2013). These indications will be further explored by evaluating the RockEval data of mudstone samples that have been obtained from the cored coal exploration borehole KB174 (GeoDoc 047E0196, Hechtel-Hoef) drilled in the Campine Basin, Belgium (Fig. 2), in 1985 (Dusar et al., 1998). The influence of depositional environment, stratigraphic position and kerogen type on hydrocarbon potential and composition and the use of palaeogeographic context as a proxy for the hydrocarbon potential of these sediments will mainly be addressed. 


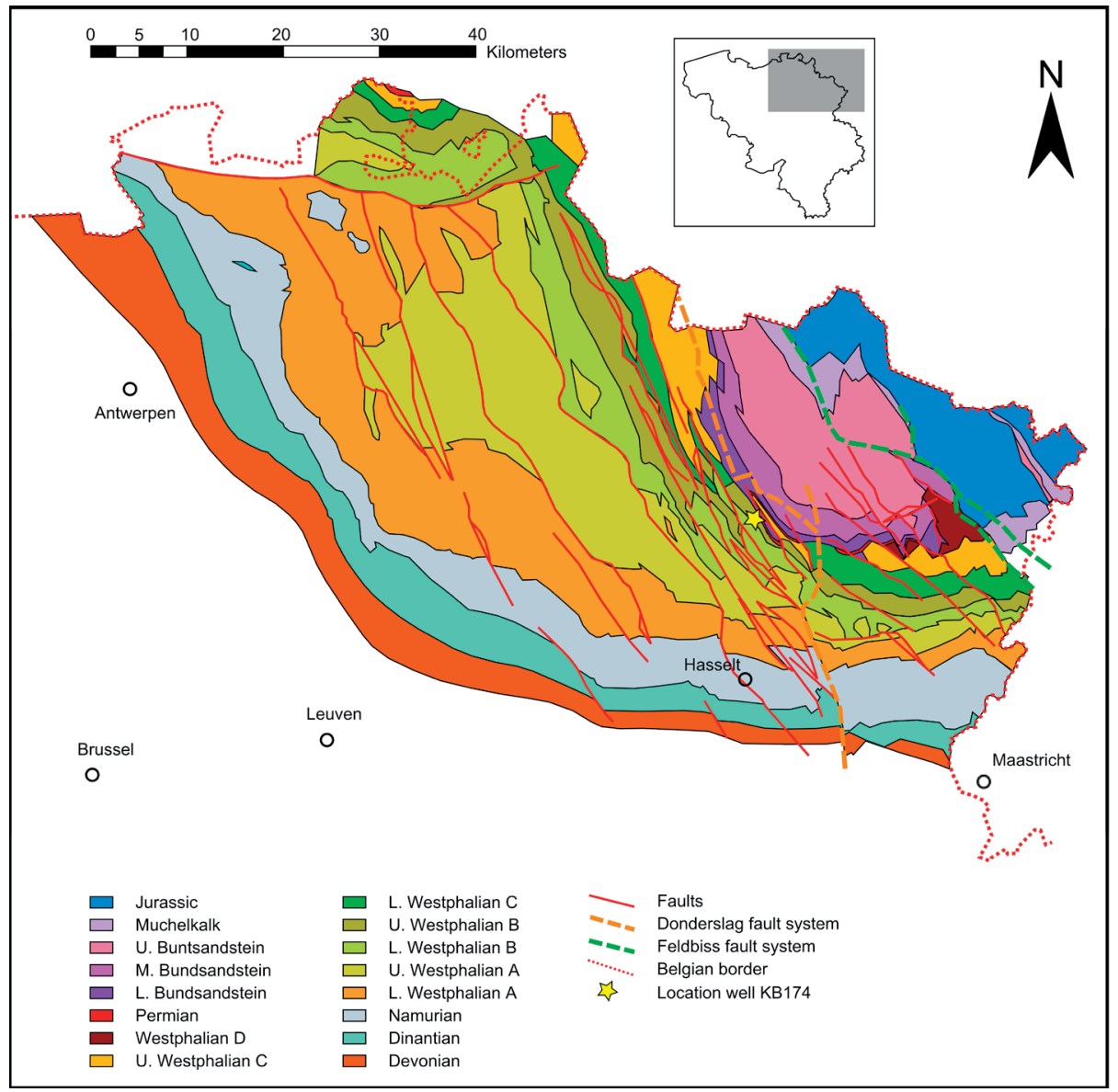

Figure 2. Pre-Cretaceous subcrop map of the Campine Basin (based on Langenaeker, 2000 and Patijn \& Kimpe, 1961), with the location of the KB174 drilling in Hechtel-Hoef.

\section{Geological setting}

The Campine Basin forms the southern part of the North West European Carboniferous Basin (Kombrink et al., 2008), situated between the London-Brabant Massif and the Roer Valley Graben. Sedimentation during the Silesian is characterised by the deposition of siliciclastic material from the northward migrating Variscan deformation front (Ziegler, 1982; Langenaeker, 2000). Shales and turbidites gradually filled the sedimentary basin during the Namurian (Collinson, 1988; Langenaeker \& Dusar, 1992). In combination with an ongoing regressive trend, the depositional setting progressively changed to delta-plain conditions. This resulted in the formation of economic coal deposits, in a swampy environment from Westphalian A to $\mathrm{C}$ (Van Buggenum \& den Hartog Jager, 2007). Slower subsidence and a more arid climate during Westphalian D finally led to the development of alluvial plains with the deposition of coarse-grained porous sandstones (Langenaeker, 2000) in dryer conditions and an overall increased sand content (Besly et al., 1993). These deposits are potential targets for geological storage of $\mathrm{CO}_{2}$ (Bertier et al., 2008; Welkenhuysen et al., 2011).

The core that was re-evaluated contains the coalbearing strata of the lower Westphalian (Fig. 3), consisting of shales, silt- and sandstones, and about $5 \%$ of coal seams (Dusar et al., 1998). These sediments were deposited in cycles from marine (euryhaline or stenohaline) over brackish to non-marine and back to marine (Paproth et al., 1996). This cyclicity might reflect the autocyclic dynamics of the sedimentary system for small-order cycles (Delmer, 1952), but also reflects a glacio-eustatic overprint for large-order cycles (Ziegler, 1989; Read, 1991; Heckel, 1994). Marine and brackish incursions occurred more frequently during the Westphalian A, when deposition took place in a lower delta plain environment. Sea level variations are characterised by fast transgressions followed by slow and steady regressions. The Quaregnon marine band at the boundary of Westphalian $\mathrm{A}$ and $\mathrm{B}$ coincides with the transition from a lower to an upper delta plain environment (Lorenzi et al., 1992; Paproth et al.,
1996). Sedimentation is influenced by the influx of erosion material from the Variscan deformation front in the southern hinterland; its northward displacement resulted in gradually higher sand content (Paproth et al., 1996). Greater gradient of the coastal plain/graded rivers resulted in a slower and more gradual transgression, less marine incursions and more pure ombrotrophic coals.

Three main periods of subsidence affecting the Westphalian strata have been identified in the Campine Basin (Van Keer et al., 1998b), corresponding to the late Namurian - Westphalian, late Permian to lower Jurassic, and finally Upper Cretaceous - Cenozoic. These phases are separated by periods of uplift during the Asturian and Kimmerian deformation phases. Synsedimentary faults play an important role in regional subsidence and burial history (Dusar, 1989). The Donderslag Fault System divides the Campine Basin into a western and eastern part. This resulted in a later maximum burial depth (Middle Jurassic) and higher maturity values for the eastern Campine Block (Langenaeker, 1992; Van Keer et al., 1998b), while maximum burial depths to the west of the Donderslag Fault were already reached at the end of the Carboniferous, i.e. at the end of the Westphalian deposition. These differences are important because timing of maturation is one of the key factors for assessing the hydrocarbon potential of a deposit. KB174 is situated to the west of the Donderslag Fault, an area where Westphalian C and D strata have been completely eroded during the Asturian uplift. The second burial phase during the Permian to early Jurassic (with maximum burial depth for the eastern Campine Block) was followed by the Cimmerian tectonic uplift phase, resulting in the erosion of hundreds of meters of Triassic to lower Jurassic sediments (Dusar et al., 2001). Later subsidence by the formation of the Roer Valley Graben resulted in the deposition of Upper Cretaceous to Cenozoic sediments. Consequently, synsedimentary and block faulting during the latest Carboniferous led to significant evolutional differences throughout the Campine Basin (Bouckaert \& Dusar, 1987; Kosters \& Donselaar, 2003). In the area of the studied borehole, to the west of the Donderslag 


\section{Westphalian B}

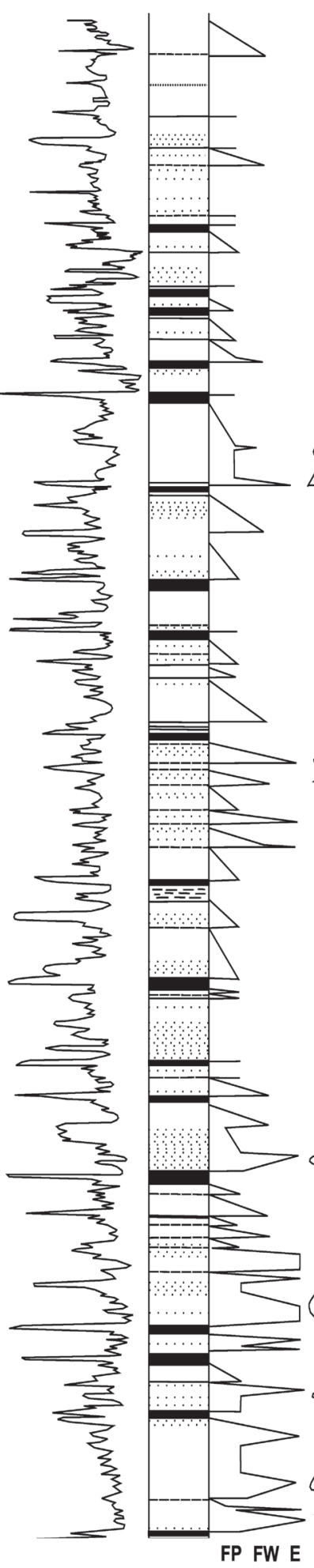

9

$8 b$

$8 a$
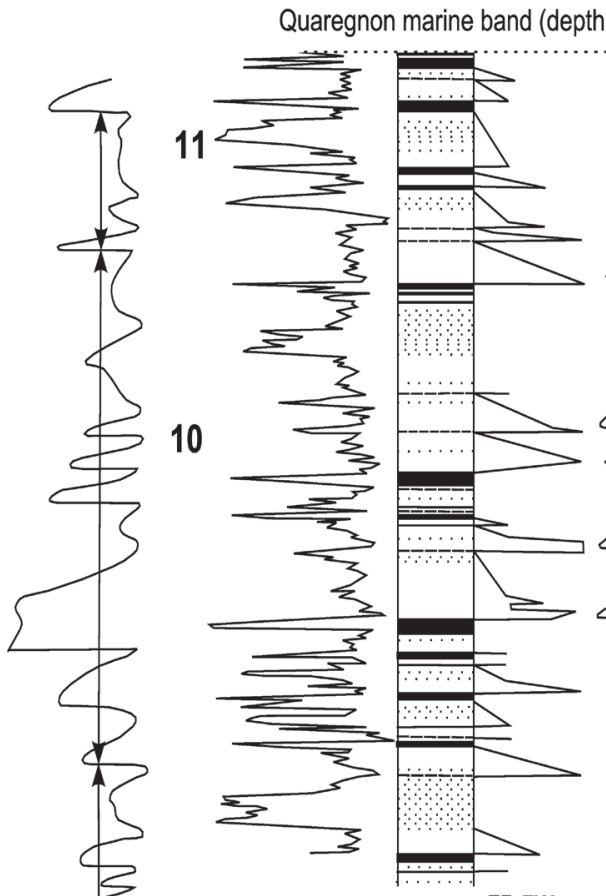

FP FW

Westphalian A

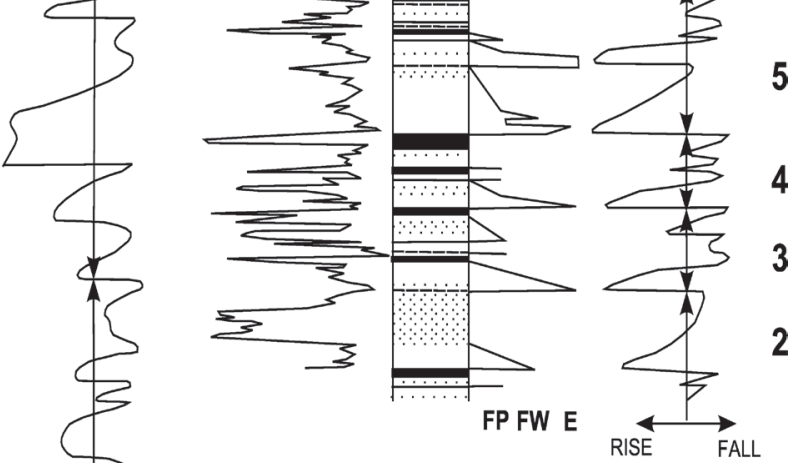

Figure 3. Simplified lithologic sequence of borehole KB174, with natural gamma ray $\log$ to the left (gamma ray range $25-175 \mathrm{API}$ ), palaeoenvironments based on faunal assemblages $(\mathrm{FP}=$ food plain, $\mathrm{FW}$ $=$ fresh water, $\mathrm{E}=$ euryhaline) and relative sea level curve to the right. Westphalian B and Westphalian A strata are respectively shown in the left and right litholog and are separated by the Quaregnon marine band, which is situated at a depth of 1293.59 meters (adapted from Paproth et al. (1996)).
Fault, it is estimated that maximum burial temperatures of 110 to $130{ }^{\circ} \mathrm{C}$ have been reached for Westphalian A and B strata during the Stephanian.

\section{Palaeogeography and depositional environment}

About 637 meters of Westphalian A and B strata have been cored in borehole KB174 (Hechtel-Hoef), containing an alternation of shale, silt- and sandstone and coal beds. These sediments have been interpreted as a fluvial-dominated delta plain complex (Dreesen, 1993), with the incursion of limnic to brackish water depositional environments. Four major palaeoenvironments have been defined by Paproth et al. (1996) in KB174, which are based on the faunal assemblage and related to the relative sea level rise and fall. These four palaeoenvironments will be explained below starting from strictly fresh water swampy to a marine influenced environment.

The Swamp palaeoenvironment (S) encompasses the coal seam beds and corresponds to a fluvial swamp environment rich in plant remains. It is typified by palaeosols, raised bogs, peat-forming swamps and marshes. 
Extensive non-marine flood plains with fluvial channels, crevasse splays and lakes represent the Non-marine Flood Plains palaeoenvironment (FP). These deposits frequently show fining upward sequences in siltstones and silty mudstones with siderite nodules, devoid of faunal content. The lake deposits usually contain non-marine bivalves and freshwater ostracods and consist of laminated mudstones with a dark-grey to black colour, rich in organic-matter and thin platy siderite lenses.

Influx of brackish water must have occurred in the Freshwater palaeoenvironment (FW), but remained sporadically. It is typified by faunal markers as bivalves Naiadites, Curvirimula and Anthraconaia, ostracod Geisina and ichnofossil Planolites montanus. Anoxic sedimentation due to stagnant water conditions resulted in the deposition of black organic-rich mudstones.

The Euryhaline palaeoenvironment (E) corresponds to the peak of the marine ingressions, represented by the marine beds. The presence of certain faunal markers, such as Planolites ophthalmoides and Cochlichnus kochi, is the major indication of euryhaline conditions.

\section{Methodology for determining the hydrocarbon potential}

The hydrocarbon potential is based on three different, not necessarily independent parameters from pyrolysis, commonly used in the evaluation of gas shales (McCarthy et al., 2011; Andrews, 2013), i.e. the total organic carbon (TOC), S2 (the methane released due to pyrolysis in $\mathrm{mg} / \mathrm{g}$ of rock) and the kerogen type. The Rock-Eval measurements by Dusar et al. (1998) were performed by Labofina according to the methodology of Espitalié et al. (1977). These three parameters will be assessed in three different parts. In a first part, we address the hydrocarbon potential and the kerogen type for the entire core. In the second and third part we focus respectively on the palaeoenvironmental setting (FP, FW and E) and stratigraphic position (Westphalian A or B). In all three parts, S2 and TOC values will be assessed to examine the hydrocarbon potential. Other Rock-Eval indices like Hydrogen Index (HI), Oxygen Index (OI) and Tmax will be used to determine the kerogen type by means of the Van Krevelen diagram, in which OI is plotted against HI (Van Krevelen, 1950; Durand \& Espitalié, 1973), or a regression line analysis of TOC plotted against S2 (Langford \& BlancValleron, 1990; Conford et al., 1998). The plotting of Tmax against $\mathrm{HI}$ provides information on the kerogen type, as well as on the maturation grade of the samples (Espitalié et al., 1977).

\section{Results}

Samples from 47 mud rock layers of borehole KB174 core directly overlying coal seams (roof shales) have been subjected to Rock-Eval II pyrolysis (Table 1) and interpreted according to the schemes outlined above.

\subsection{Hydrocarbon Potential of the Hechtel-Hoef roof shales}

The source rock potential of the Westphalian A/B shales has been determined by re-evaluating the Rock-Eval data published by Dusar et al. (1998), shown in Table 1. S2 values vary from 0.3 to $58.0 \mathrm{mg} / \mathrm{g}$, with an average of $7.9 \mathrm{mg} / \mathrm{g}$. TOC shows an average of $3.6 \%$, ranging between 0.55 and $16.72 \%$. The Hydrogen Index varies between 58.2 and $478.2 \mathrm{mg} / \mathrm{g}$, with an average of $164.2 \mathrm{mg} / \mathrm{g}$.

In the Van Krevelen diagram (Fig. 4a) three different groups can be identified. The first one can be identified on the left or along the maturation path of kerogen types I and II. Because both maturation paths coincide, it is impossible to make a distinction between kerogen types. In general these samples have Oxygen Indices below $20 \mathrm{mg} / \mathrm{g}$. On the other end of the spectrum, at Oxygen Index values above $50 \mathrm{mg} / \mathrm{g}$, the samples plot along the maturation path of kerogen type III. The remaining samples plot in a third cluster with Oxygen Indices between 20 and $50 \mathrm{mg} / \mathrm{g}$, implying they consist of a mixture of kerogen type III and I/II.

Nearly all samples plot between the lines for kerogen types II and III on the plot of Tmax against the Hydrogen Index (Fig. 4b). Consequently all the samples that occur within the first cluster on the Van Krevelen diagram can be assigned to maturation path line of kerogen type II on Figure 4a. Nonetheless, also these samples show some mixing with kerogen type III. The data points on Figure $4 \mathrm{~b}$ clearly plot within the oil window.

The regression line on the S2 vs. TOC plot (Fig. 4c) indicates a mixture of kerogen type II and III for the studied roof shale samples. Samples with low TOC values have relatively low $\mathrm{S} 2$ values and tend towards kerogen type III.

\subsection{Palaeoenvironment}

The Rock-Eval measurements in Table 1 clearly show a distinction between the different palaeoenvironments. The highest average TOC and S2 values $(4.2 \%$ and $9.5 \mathrm{mg} / \mathrm{g})$ are found in flood plain environments. In general there is a large spread in Oxygen Index, with an average of $58.2 \mathrm{mg} / \mathrm{g}$. The majority of the samples plot between HI values of 100 and

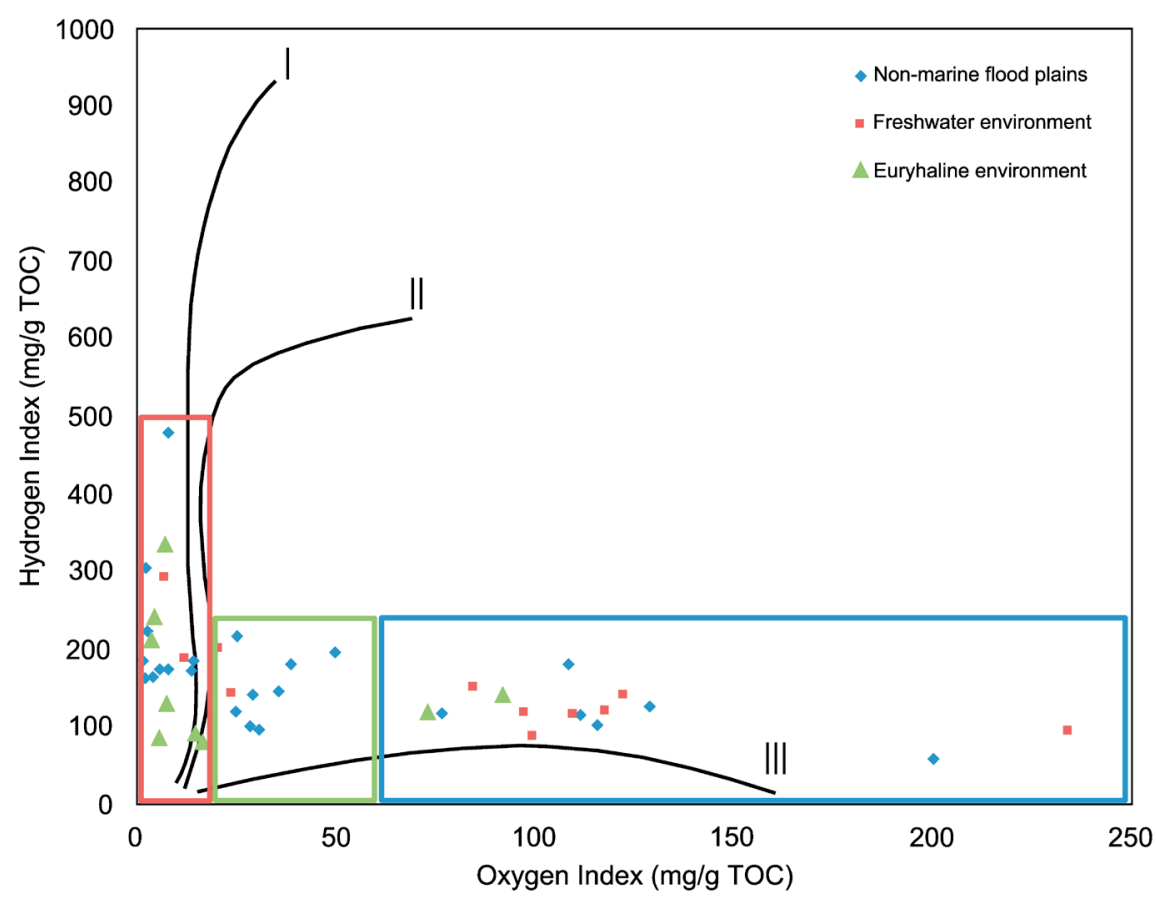

Figure 4a. Van Krevelen diagram showing that all the different palaeoenvironments contain a mixture of kerogen types II and III. The red box gathers the data points that plot along the maturation line of kerogen types I and II, while the blue box restricts the kerogen type III data points. It is not possible in the red box to distinguish the samples that are enriched in kerogen type I or II. The green box defines the samples that fall in between. 
Figure 4b. Plot of Tmax vs. Hydrogen Index shows that nearly all the samples are located within the oil window. All data points plot between the migration path lines of kerogen types II and III. Non-marine flood plain samples and the euryhaline environment plot closely to the migration path line of kerogen type II, while the fresh water samples plot more closely towards kerogen type III. This plot also shows that the data points in the red box of the Van Krevelen diagram (Fig. 4a) are of kerogen type II.

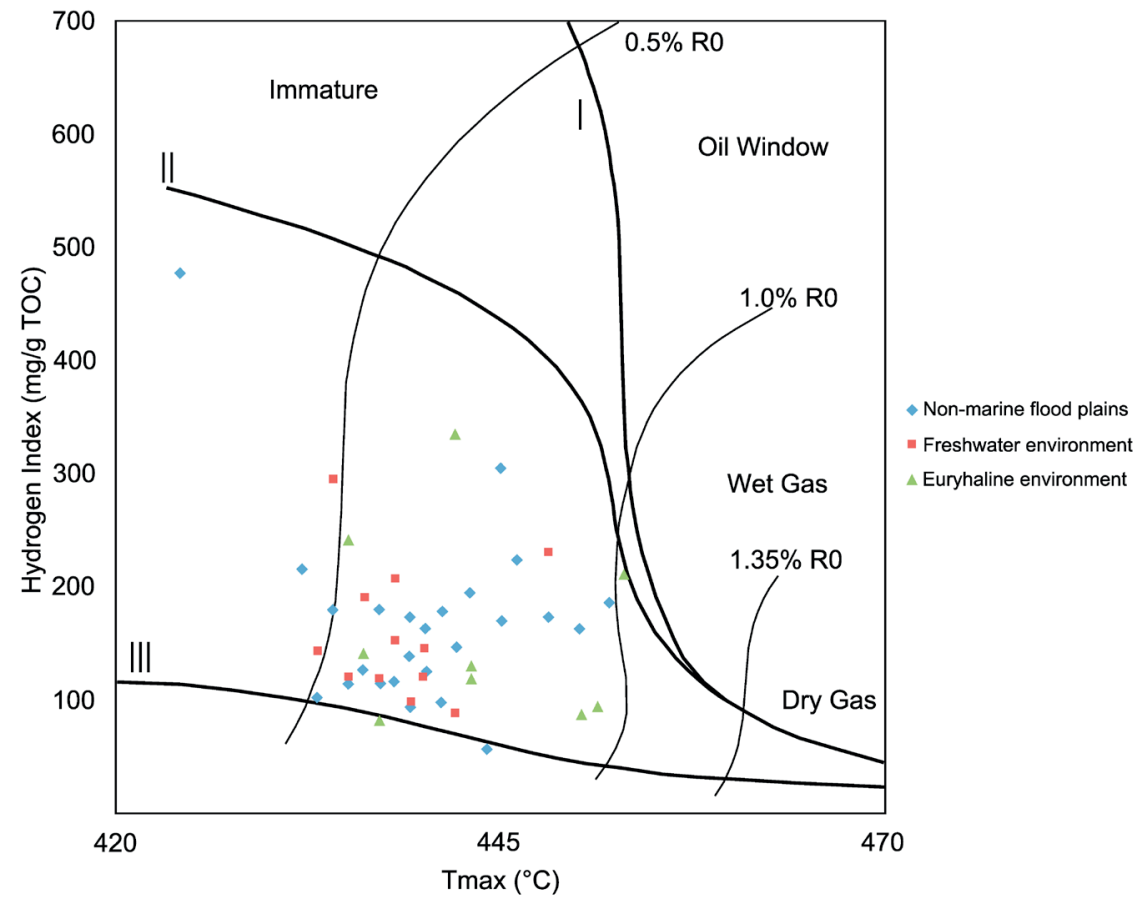

$200 \mathrm{mg} / \mathrm{g}$ with an average of $169.6 \mathrm{mg} / \mathrm{g}$. HI values above $200 \mathrm{mg} / \mathrm{g}$ are rare. The samples from freshwater environments have average TOC and S2 of respectively $2.53 \%$ and $5.5 \mathrm{mg} / \mathrm{g}$ and average HI and OI values of 77.0 and $159.7 \mathrm{mg} / \mathrm{g}$. With the exception of two outliers, the majority of the nine samples from euryhaline settings cluster around OI values of about $20 \mathrm{mg} / \mathrm{g}$. Average Oxygen and Hydrogen Index are 24.7 and $161.8 \mathrm{mg} / \mathrm{g}$ respectively. The average TOC and $\mathrm{S} 2$ are $3.7 \%$ and $7.6 \mathrm{mg} / \mathrm{g}$. All the TOC, S2, HI and OI averages are summarized in Table 2.

Subtle differences in kerogen type dominance between the depositional settings can be observed on the Van Krevelen diagram (Fig. 4a). Except for two data points, samples from an euryhaline setting plot in the proximity of the kerogen type I and II maturation lines. The samples of both the fresh water environment and the non-marine flood plain environment plot on all the maturation paths. The difference between both is that the first shows a bimodal distribution while the data points of the flood plain environment are more spread out along the entire segment. The plot of Tmax versus Hydrogen Index (Fig. 4b) shows that the data points of the different palaeoenvironments are situated between the maturation path lines of kerogen type II and III, suggesting a kerogen type II and III mixture for all the three palaeoenvironments. The order in terms of kerogen type II dominance deduced from the Van Krevelen diagram (Fig. 4a) is also reflected in this plot. Samples of the fresh water realm have on average the lowest maturity and Hydrogen Index and thus plot closest to the maturation path of kerogen type III. On average flood plain samples have a higher Hydrogen Index than those from an euryhaline environment, but the difference in Tmax indicates the latter plots closer to the maturation path of kerogen type II. In summary the euryhaline palaeoenvironment has the highest contribution in kerogen type II. Nevertheless it can be observed that the differences with the flood plain environment are small.

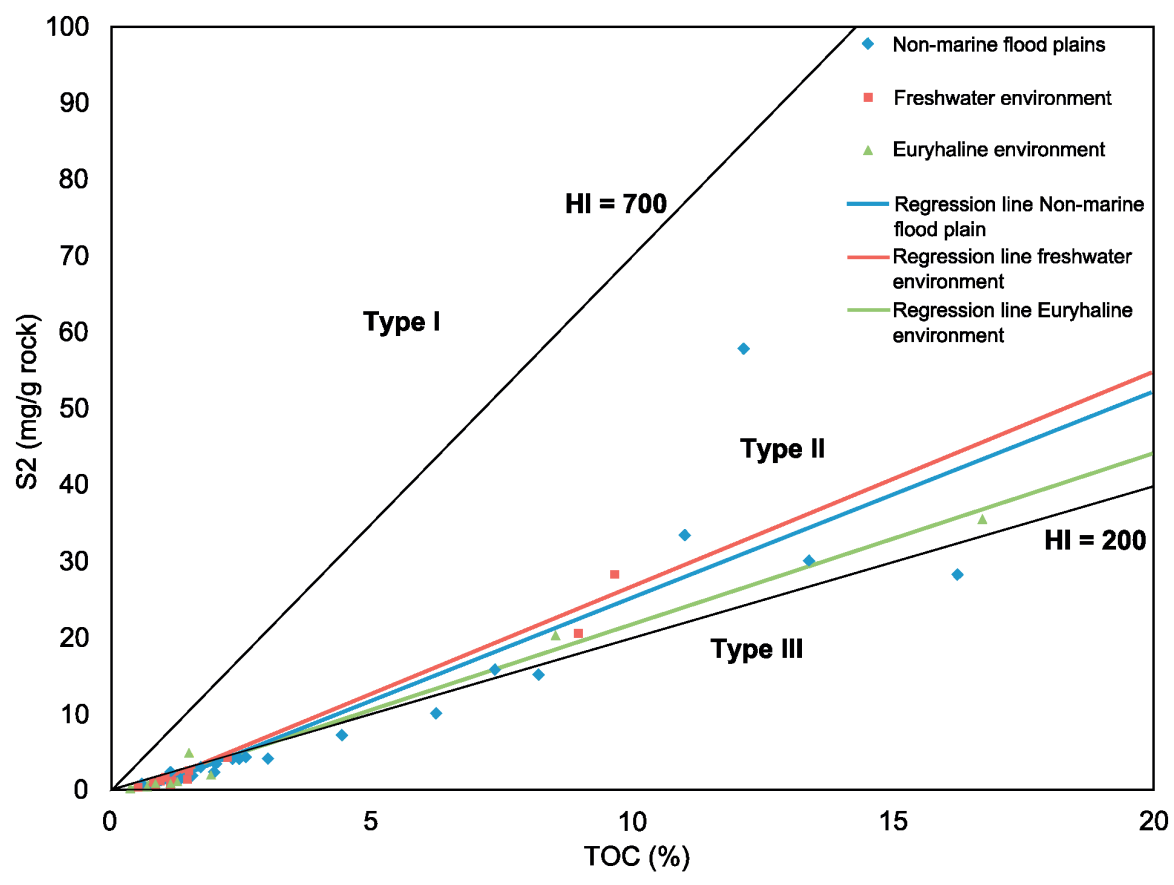

Figure 4c. The regression line analysis of the $\mathrm{S} 2 \mathrm{vs}$. TOC plot indicates that the samples of the KB174 drilling are of a kerogen type II - III mixture. It is observed that the regression lines of non-marine flood plains and the fresh water environment are most dominant in kerogen type II. This is in contrast with the observations made from Figures $4 \mathrm{a}$ and $4 \mathrm{~b}$. 


\begin{tabular}{|c|c|c|c|c|c|c|c|c|c|c|}
\hline $\begin{array}{l}\text { Roof } \\
\text { layer }\end{array}$ & $\begin{array}{l}\text { Depth } \\
\text { (m) }\end{array}$ & $\begin{array}{l}\mathrm{S} 1 \\
(\mathrm{mg} / \mathrm{g})\end{array}$ & $\begin{array}{l}\mathrm{S} 2 \\
(\mathrm{mg} / \mathrm{g})\end{array}$ & $\begin{array}{l}\text { S3 } \\
(\mathrm{mg} / \mathrm{g})\end{array}$ & $\mathrm{S} 2 / \mathrm{S} 3$ & $\begin{array}{l}\text { Tmax } \\
\left({ }^{\circ} \mathrm{C}\right)\end{array}$ & $\begin{array}{l}\text { TOC } \\
(\%)\end{array}$ & $\begin{array}{l}\mathrm{HI} \\
(\mathrm{mg} / \mathrm{g} \\
\mathrm{TOC})\end{array}$ & $\begin{array}{l}\begin{array}{l}\text { OI } \\
(\mathrm{mg} / \mathrm{g}\end{array} \\
\mathrm{TOC})\end{array}$ & Palaeoenvironment \\
\hline 2 & 869.00 & 0.10 & 2.82 & 0.17 & 16.59 & 436.00 & 1.47 & 191.84 & 11.56 & Freshwater \\
\hline 5 & 901.30 & 0.12 & 1.19 & 1.01 & 1.18 & 433.00 & 0.83 & 143.37 & 121.69 & Freshwater \\
\hline 6 & 916.50 & 1.64 & 57.96 & 0.95 & 61.01 & 424.00 & 12.12 & 478.22 & 7.84 & Non-marine flood plain \\
\hline 7 & 919.70 & 0.13 & 4.21 & 0.86 & 4.90 & 439.00 & 3.01 & 139.87 & 28.57 & Non-marine flood plain \\
\hline 9 & 937.50 & 0.14 & 0.85 & 0.86 & 0.99 & 436.00 & 0.67 & 126.87 & 128.36 & Non-marine flood plain \\
\hline 10 & 944.20 & 0.15 & 3.11 & 1.86 & 1.67 & 434.00 & 1.72 & 180.81 & 108.14 & Non-marine flood plain \\
\hline 11 & 952.10 & 0.09 & 0.85 & 0.96 & 0.89 & 433.00 & 0.83 & 102.41 & 115.66 & Non-marine flood plain \\
\hline 12 & 959.60 & 0.16 & 4.56 & 0.43 & 10.60 & 438.00 & 2.20 & 207.27 & 19.55 & Freshwater \\
\hline 14 & 984.30 & 0.22 & 1.76 & 1.40 & 1.26 & 435.00 & 1.45 & 121.38 & 96.55 & Freshwater \\
\hline 14 & 995.60 & 0.10 & 5.03 & 0.10 & 50.30 & 442.00 & 1.49 & 337.58 & 6.71 & Euryhaline \\
\hline 15 & 1009.30 & 0.10 & 0.90 & 0.83 & 1.08 & 437.00 & 0.76 & 118.42 & 109.21 & Freshwater \\
\hline 16 & 1021.10 & 0.16 & 4.45 & 0.20 & 22.25 & 439.00 & 2.55 & 174.51 & 7.84 & Non-marine flood plain \\
\hline 18 & 1044.80 & 0.10 & 1.04 & 0.33 & 3.15 & 439.00 & 1.08 & 96.30 & 30.56 & Non-marine flood plain \\
\hline 19 & 1061.50 & 0.16 & 1.46 & 0.80 & 1.83 & 438.00 & 0.95 & 153.68 & 84.21 & Freshwater \\
\hline 21 & 1078.90 & 3.71 & 28.53 & 0.62 & 46.02 & 434.00 & 9.65 & 295.65 & 6.42 & Freshwater \\
\hline 22 & 1085.50 & 0.14 & 1.03 & 0.21 & 4.90 & 438.00 & 0.87 & 118.39 & 24.14 & Non-marine flood plain \\
\hline 23 & 1090.10 & 0.16 & 1.20 & 0.77 & 1.56 & 436.00 & 0.84 & 142.86 & 91.67 & Euryhlaine \\
\hline 24 & 1096.40 & 2.02 & 20.66 & 0.34 & 60.76 & 435.00 & 8.49 & 243.35 & 4.00 & Euryhaline \\
\hline 25 & 1106.40 & 0.12 & 2.23 & 2.16 & 1.03 & 435.00 & 1.94 & 114.95 & 111.34 & Non-marine flood plain \\
\hline $25 b$ & 1111.90 & 0.30 & 7.23 & 0.17 & 42.53 & 440.00 & 4.40 & 164.32 & 3.86 & Non-marine flood plain \\
\hline 27 & 1128.80 & 0.17 & 0.83 & 0.28 & 2.96 & 439.00 & 0.78 & 106.41 & 35.90 & Swamp \\
\hline 27 & 1133.60 & 0.08 & 1.56 & 1.01 & 1.54 & 437.00 & 1.32 & 118.18 & 76.52 & Non-marine flood plain \\
\hline 29 & 1166.30 & 0.25 & 4.22 & 0.90 & 4.69 & 437.00 & 2.33 & 181.12 & 38.63 & Non-marine flood plain \\
\hline 29 & 1168.30 & 0.07 & 1.11 & 2.66 & 0.42 & 439.00 & 1.14 & 97.37 & 233.33 & Freshwater \\
\hline 30 & 1190.10 & 0.07 & 1.06 & 1.02 & 1.04 & 440.00 & 0.87 & 121.84 & 117.24 & Freshwater \\
\hline 31 & 1195.10 & 0.64 & 15.91 & 1.82 & 8.74 & 432.00 & 7.33 & 217.05 & 24.83 & Non-marine flood plain \\
\hline $32 \mathrm{c}$ & 1204.10 & 0.13 & 1.86 & 5.96 & 0.31 & 440.00 & 1.51 & 123.18 & 394.70 & Non-marine flood plain \\
\hline 33 & 1221.80 & 0.13 & 1.37 & 0.22 & 6.23 & 440.00 & 0.94 & 145.74 & 23.40 & Freshwater \\
\hline 33 & 1233.90 & 0.11 & 2.52 & 0.14 & 18.00 & 443.00 & 1.91 & 131.94 & 7.33 & Euryhaline \\
\hline 34 & 1241.90 & 0.05 & 0.57 & 0.11 & 5.18 & 437.00 & 0.68 & 83.82 & 16.18 & Euryhaline \\
\hline 36 & 1258.10 & 0.16 & 3.58 & 0.27 & 13.26 & 441.00 & 1.99 & 179.90 & 13.57 & Non-marine flood plain \\
\hline 37 & 1278.60 & 0.07 & 0.90 & 0.54 & 1.67 & 443.00 & 0.74 & 121.62 & 72.97 & Euryhaline \\
\hline 37 & 1282.30 & 0.18 & 2.25 & 0.57 & 3.95 & 443.00 & 1.15 & 195.65 & 49.57 & Non-marine flood plain \\
\hline 38 & 1293.50 & 0.06 & 0.57 & 0.16 & 3.56 & 441.00 & 0.57 & 100.00 & 28.07 & Non-marine flood plain \\
\hline 40 & 1305.50 & 0.13 & 2.07 & 0.50 & 4.14 & 442.00 & 1.41 & 146.81 & 35.46 & Non-marine flood plain \\
\hline 41 & 1321.50 & 0.04 & 0.32 & 1.10 & 0.29 & 444.00 & 0.55 & 58.18 & 200.00 & Non-marine flood plain \\
\hline $41 b$ & 1326.20 & 0.07 & 1.00 & 1.11 & 0.90 & 442.00 & 1.12 & 89.29 & 99.11 & Freshwater \\
\hline $44 \mathrm{cc}$ & 1381.50 & 13.46 & 28.24 & 0.94 & 30.04 & 448.00 & 16.25 & 173.78 & 5.78 & Non-marine flood plain \\
\hline 46 & 1405.10 & 1.25 & 33.57 & 0.20 & 167.85 & 445.00 & 11.01 & 304.90 & 1.82 & Non-marine flood plain \\
\hline 47 & 1409.40 & 0.16 & 4.24 & 0.33 & 12.85 & 445.00 & 2.49 & 170.28 & 13.25 & Non-marine flood plain \\
\hline 48 & 1433.60 & 1.12 & 20.63 & 0.16 & 128.94 & 448.00 & 8.94 & 230.76 & 1.79 & Freshwater \\
\hline 50 & 1444.00 & 0.84 & 10.06 & 0.14 & 71.86 & 450.00 & 6.20 & 162.26 & 2.26 & Non-marine flood plain \\
\hline 51 & 1451.60 & 0.13 & 1.17 & 0.18 & 6.50 & 451.00 & 1.25 & 93.60 & 14.40 & Euryhaline \\
\hline $52 \mathrm{a}$ & 1459.20 & 3.23 & 30.07 & 0.28 & 107.39 & 446.00 & 13.36 & 225.07 & 2.10 & Non-marine flood plain \\
\hline 53 & 1471.30 & 0.15 & 0.98 & 0.06 & 16.33 & 450.00 & 1.12 & 87.50 & 5.36 & Euryhaline \\
\hline $54 \mathrm{a}$ & 1490.80 & 2.28 & 35.71 & 0.56 & 63.77 & 453.00 & 16.72 & 213.58 & 3.35 & Euryhaline \\
\hline $54 \mathrm{~b}$ & 1494.50 & 0.94 & 15.29 & 0.12 & 127.42 & 452.00 & 8.18 & 186.92 & 1.47 & Non-marine flood plain \\
\hline
\end{tabular}

Table 1. Rock-Eval parameters of the KB174 drill core in Hechtel-Hoef (Campine Basin, NE Belgium). 


\subsection{Stratigraphic position}

Roof shales with a high TOC content $(>4 \%)$ occur more frequently in the upper Westphalian A compared to the lower Westphalian B (Fig. 5), resulting in a difference in average TOC between Westphalian A (6.4\%) and Westphalian B $(2.4 \%)$ (Table 2). The same observation was made for the S2 values, where Westphalian A and B samples showed averages of respectively 13.1 and $5.7 \mathrm{mg} / \mathrm{g}$. These differences in TOC and $\mathrm{S} 2$ are shown in Figure 6.

\begin{tabular}{lcc}
\hline & TOC (\%) & S2 (mg/g) \\
\hline Non-marine flood plains & 4.2 & 9.5 \\
Freshwater environment & 2.5 & 5.5 \\
Euryhaline environment & 3.7 & 7.6 \\
Westphalian A & 6.4 & 13.1 \\
Westphalian B & 2.4 & 5.7 \\
\hline
\end{tabular}

Table 2. Average TOC and S2 values for each palaeoenvironment and stratigraphic unit.

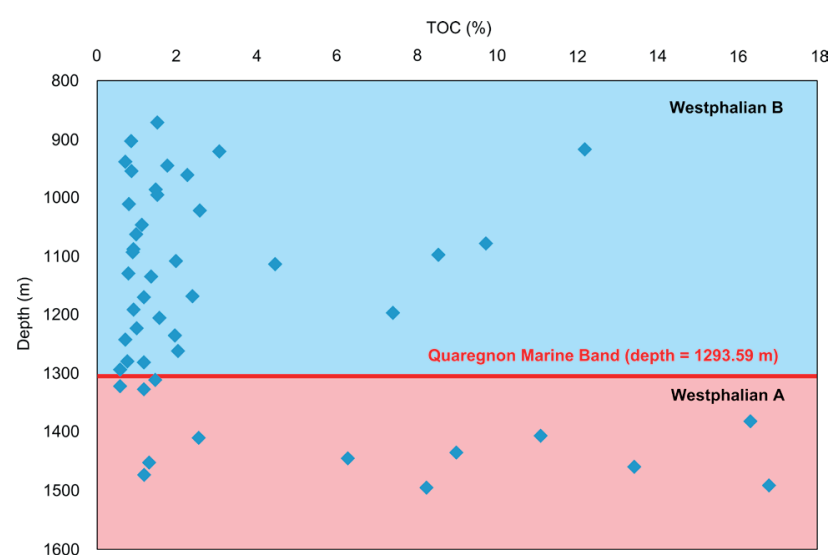

Figure 5. Total Organic Carbon (TOC) in function of depth (in meters). It is observed that in Westphalian A, below the Quaregnon Member, there are relative more samples with high TOC values.

In the Van Krevelen diagram (Fig. 7a) nearly all Westphalian A data points have an Oxygen Index below $40 \mathrm{mg} / \mathrm{g}$, plotting nearby the maturation paths of kerogen types I and II. Only 2 of the 14 data points have high OI and low HI values and plot along the maturation path of kerogen type III. The average Hydrogen and Oxygen Index for the entire stratigraphic unit are respectively 160.2 and $29.6 \mathrm{mg} / \mathrm{g}$. Westphalian B samples have slightly higher average Hydrogen and Oxygen Index of respectively 166.0 and $67.3 \mathrm{mg} / \mathrm{g}$. When the samples in the Van Krevelen diagram (Fig. 7a) are grouped into the same clusters as on Figure $4 \mathrm{a}$, it can be observed that the samples of Westphalian B are more equally divided over the three clusters. Westphalian A on the contrary is mainly present in the Type I cluster at OI values below $20 \mathrm{mg} / \mathrm{g}$, which indicates that kerogen type II is more prevalent in Westphalian A than in Westphalian B. The Tmax vs. Hydrogen Index plot (Fig. 7b) shows that both stratigraphic units have a similar hydrogen index. The Tmax values of Westphalian A are generally higher than those of Westphalian B, suggesting these samples are more mature. Despite this difference in maturity, the difference in hydrogen index between both stratigraphic units is negligible. Together with the significant lower average oxygen index, this indicates that the contribution of kerogen type II is larger in Westphalian A than in Westphalian B.

\section{Discussion}

\subsection{Influence of kerogen type and palaeoenvironment on the hydrocarbon potential}

The organic matter present in the sediment is a mixture of kerogen type II and III, reflecting the limnic environments with organic sediment of both local (lake-origin type II) and fluvial influx of humic debris of kerogen type III from the uplands. The presence of kerogen type II in the sediment is atypical for a coal environment. This organic content has not only consequences for the hydrocarbon potential, which increases when organic material with higher hydrogen content is present, but also the composition of hydrocarbons generated. The presence of kerogen type II in the sediment indicates the capability of producing high-molecular-weight hydrocarbons, i.e. oil (Tissot et al., 1974).

The euryhaline environment has the largest fraction of kerogen type II, according to the Van Krevelen diagram and the plot of Tmax and HI (Figs 4a and 4b). This is in agreement with the presence of a brackish fauna reflecting minor marine incursions (Paproth et al., 1996). These observations are in contradiction with the regression line analysis of the TOC S2 plot (Fig. 4c), where the dominant kerogen type II content can be attributed to the fresh water environment. Nonetheless, the outcome of a linear regression may be misleading and disguise the real influences, implying that findings should be approached with care. Two parameters can substantially influence the analysis and lead to misinterpretation, i.e. high HI values of organic-rich samples and the mineral matrix effect (Dembicki Jr., 2009).

Organic-rich samples with high $\mathrm{HI}$ values will increase the slope of the regression line and thus bias the interpretation towards kerogen types with lower oxygen contents, as observed for the flood plain deposits in Figure 4c. Mineral components play a dominant role in sediments with a TOC lower than $2 \%$ (63\% of all the Hechtel-Hoef roof shale samples) by retaining hydrocarbons to their surfaces, resulting in a systematic underestimation of the Hydrogen Index (Espitalié et al., 1980; Katz, 1983; Dembicki Jr., 2009). This effect, known as the mineral matrix effect (Langford \& Blanc-Valleron, 1990), will also result in a stronger inclination of the regression line, as observed for the fresh water environment. Both phenomena indicate that an interpretation based on the regression analysis
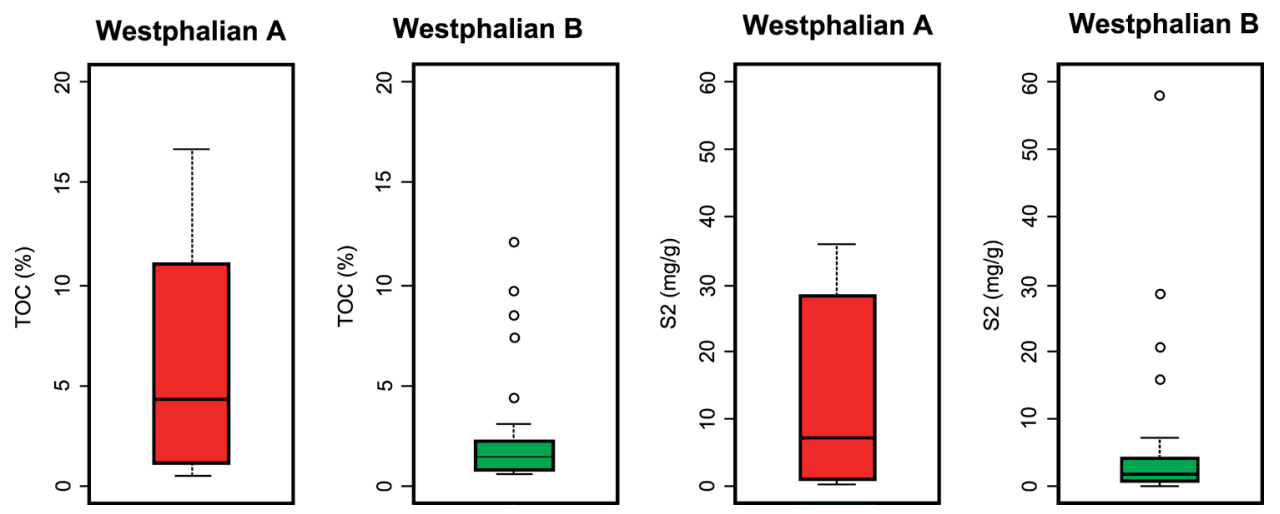

Figure 6. Boxplot of TOC and S2 for Westphalian A and B. Here it can be seen that in general the TOC and $\mathrm{S} 2$ values of Westphalian $\mathrm{A}$ are higher than for Westphalian B. The high S2 and TOC values for Westphalian $\mathrm{B}$ can be regarded as outliers. 


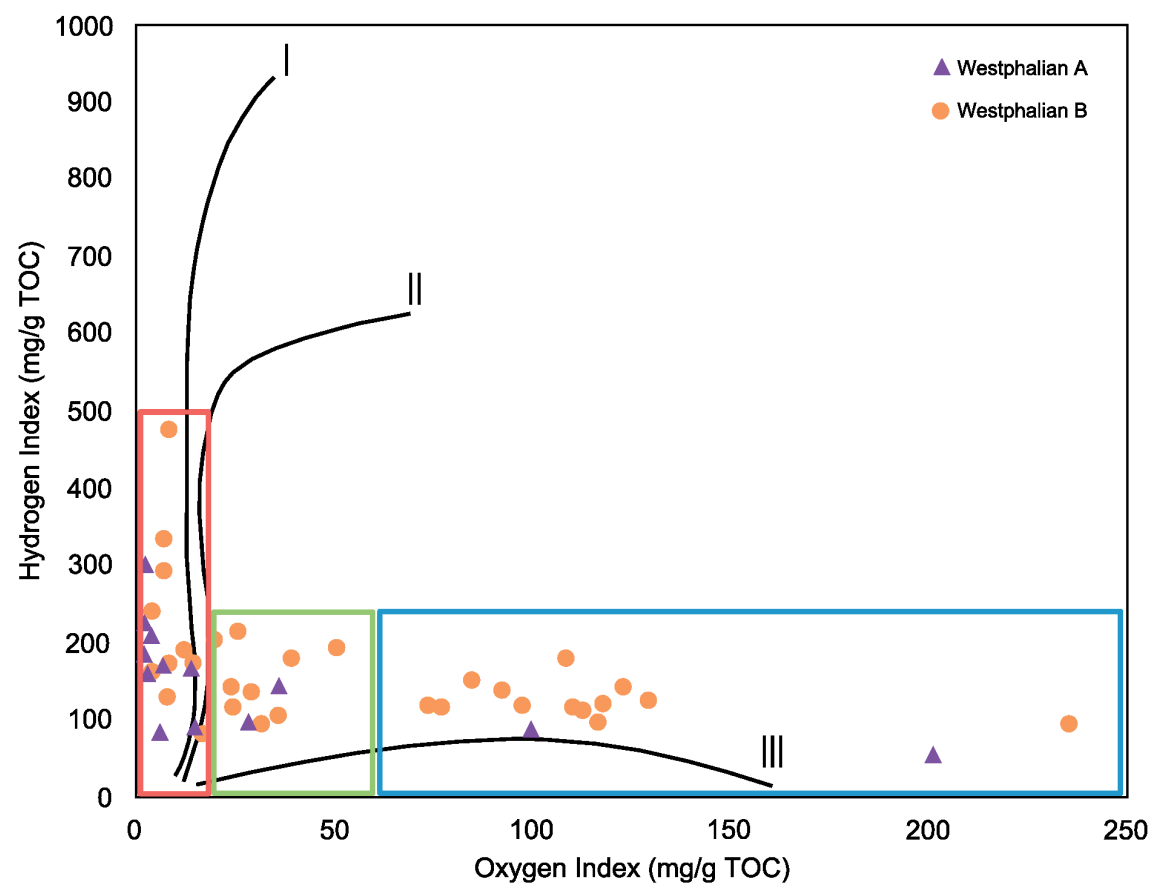

Figure 7a. The Van Krevelen diagram shows that in general the Westphalian A samples plot towards the migration path lines of kerogen types I and II, while Westphalian B mainly plots along the kerogen type III path line. The three boxes of the Van Krevelen diagram in Figure 4a are also shown in this diagram for comparison. It is observed that the majority of the Westphalian A samples plot in the red box, while Westphalian B is more equally divided along all the three boxes.

of Figure $4 \mathrm{c}$ leads to an overestimation of the contribution of kerogen type II in the sediment. From this is concluded that samples of the fresh water and flood plain environment have a lower kerogen type II content compared to the euryhaline setting.

Palaeoenvironments with high kerogen type II content, such as the euryhaline environment, are expected to have a larger hydrocarbon potential. Nonetheless, the TOC and S2 values indicate that the flood plain deposits have the highest hydrocarbon potential, followed by the euryhaline and fresh water deposits. This suggests that other factors besides kerogen type play an important role. Depositional environments favouring the sedimentation of organic matter and preservation during burial will develop sediments with an increased organic content. These factors could be an explanation for the high TOC values for the flood plain samples. They contain organic matter of limnic origin, which includes kerogen type II, and have the highest hydrocarbon potential, despite not being the most kerogen type II enriched environment. In other words, the hydrocarbon potential of a depositional environment is a trade-off between the organic composition and its richness in organic matter. Palaeoenvironment could be regarded as a key to estimate the hydrocarbon potential of coastal plain mud deposits.

\subsection{Difference in hydrocarbon potential between Westphalian $A$ and $B$}

When the average TOC and S2 values are examined it is clear that samples of Westphalian A (TOC $=6.4 \%, \mathrm{~S} 2=13.1$ $\mathrm{mg} / \mathrm{g}$ ) have a higher hydrocarbon potential than those of Westphalian B (TOC $=2.4 \%, \mathrm{~S} 2=5.7 \mathrm{mg} / \mathrm{g}$ ). This difference can be assigned to the larger contribution of kerogen type
Figure 7b. Plot of Tmax vs Hydrogen Index shows that Westphalian A samples are more mature and plot closer to the migration path line of kerogen type II than Westphalian B samples.

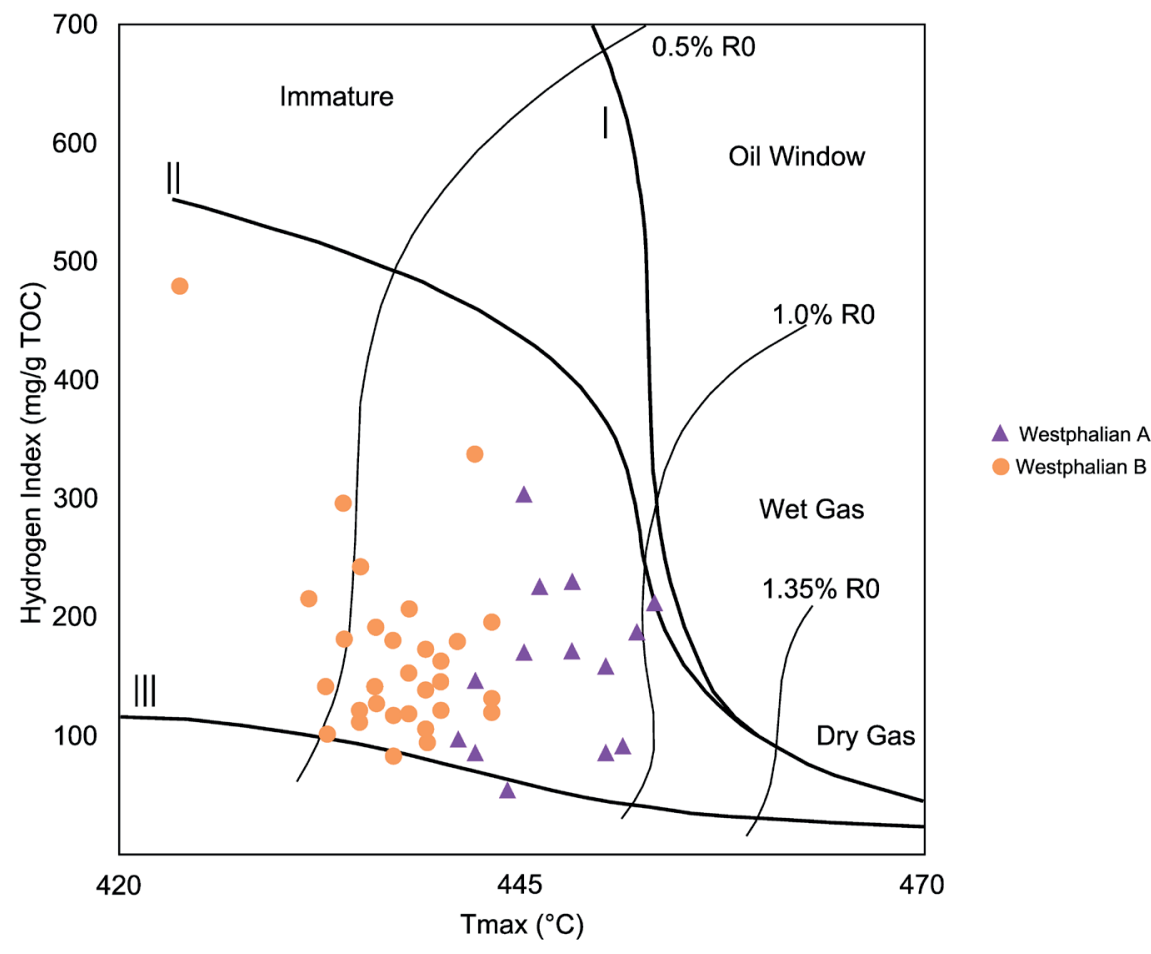


II in the roof shale deposits of Westphalian A (Figs 7a and $7 b)$. The rare Westphalian B samples high in TOC have a pronounced type II signature, indicating that there are certain levels of interest in Westphalian B composed of organic-rich bituminous shales.

It is observed that the different palaeoenvironments occur in different proportions in both stratigraphic units (Table 1). Deposits from the flood pain and the euryhaline settings have the highest TOC averages and can be considered as environments with the largest sedimentation and preservation rates of organic matter. These are dominantly present in Westphalian A (12 out of 14 samples) and proportionally less frequent in Westphalian B (22 out of 32 samples).

The palaeogeographic setting exerted a major control on the occurrence of these depositional environments. The change from lower to upper delta plain environment occurring at the transition between Westphalian A and B led to a decrease in 'wet' environments in the Westphalian B. The higher inclination of the delta plain would have resulted in more high-energy environments, while the progradation of the Variscan deformation front increased the influx of erosional material. This evolution reduced the environments favourable for sedimentation of organic matter, resulting in a lower hydrocarbon potential for Westphalian B compared to Westphalian A.

\begin{tabular}{lcccc}
\hline Eagle Ford Shale & $\mathrm{Tmax}\left({ }^{\circ} \mathrm{C}\right)$ & $\mathrm{TOC}(\%)$ & $\mathrm{S} 2(\mathrm{mg} / \mathrm{g})$ & $\mathrm{HI}(\mathrm{mg} / \mathrm{g}$ TOC) \\
\hline Outcrop (Lampasas) & 425 & 11.5 & 54.4 & 475 \\
Expo (Brown) & 434 & 4.7 & 18.2 & 392 \\
Cuttings (Various) & 462 & 2.7 & 2.0 & 72 \\
Cuttings (Various) & 439 & 2.9 & 6.6 & 227 \\
Oryx 1 Grant (core) (Montague) & 446 & 4.7 & 14.1 & 300 \\
\hline Westphalian shale & & & & \\
\hline Total & 440 & 3.6 & 7.9 & 164.2 \\
Non-marine flood plains & 440 & 4.2 & 9.5 & 169.6 \\
Freshwater environment & 438 & 2.5 & 5.5 & 159.7 \\
Euryhaline environment & 443 & 3.7 & 7.6 & 161.8 \\
Westphalian A & 447 & 6.4 & 13.1 & 160.2 \\
Westphalian B & 437 & 2.4 & 5.7 & 165.9 \\
\hline
\end{tabular}

Table 3. Comparison of the Hechtel-Hoef roof shale with the marine Eagle Ford Shale sampled by Robinson (1997) at two outcrop locations, nl. Waco and Austin.

\subsection{Putting the hydrocarbon potential into perspective}

So far the hydrocarbon potential of these roof shales has been discussed in function of the dominant kerogen type, the palaeoenvironmental context and the positioning within the stratigraphic column. It was concluded that samples from the flood plain environment and Westphalian A have the highest hydrocarbon potential. However, these findings do not directly demonstrate the economic value of these shale deposits.

Andrews (2013) gives an overview of several criteria that define a shale gas play, like minimum depth, shale porosity and thermal maturity for instance. In Rock-Eval pyrolysis, the Tmax value is useful in characterizing the thermal evolution of organic matter, but cannot be accounted as a reliable proxy for thermal maturity. The Tmax - HI plot (Fig. 4b) indicates that the large majority of the samples are situated within the oil window. Data on the vitrinite reflectance of the Westphalian A and B Hechtel-Hoef coal seams range between 0.66 and $0.97 \%$ (Dusar et al., 1998). According to the coal classification system (McCartney \& Teichmüller, 1972 and 1974) this corresponds to maturities of coalfields containing volatile bituminous coals. The Rock-Eval pyrolysis and vitrinite reflectance measurements yield the same maturity stages. In terms of thermal maturity, a cut-off value of $1.1 \%$ $\mathrm{R}_{0}$ is suggested for shale gas (Smith et al., 2010; Charpentier \& Cook, 2011), indicating the Hechtel-Hoef roof shales are not mature enough to classify as gas shales, but are capable of producing oil.

S2 and TOC are used for source rock evaluation. Different classification schemes are in place, all with different cut-off values. Nonetheless, most of them seem to agree that shale deposits with TOC and S2 values above respectively $1 \%$ and $5 \mathrm{mg} / \mathrm{g}$ can be regarded as good source rocks (Peters \& Cassa, 1994; McCarthy et al., 2011; Andrews, 2013; Liu et al., 2015). According to Peters \& Cassa (1994), all the different palaeoenvironments and stratigraphic units can be classified as good to very good source rocks, considering their average $\mathrm{S} 2$ and TOC values (Table 2 ). When these values are compared with a black marine shale in production, like the Eagle Ford Shale from the Western Gulf Basin (Texas, USA), it can be observed that in general Hechtel-Hoef roof shales show lower S2 and HI values for samples with a similar TOC content (Table 3) (Robinson, 1997). The reason for this is twofold. The maturity of the Westphalian samples is in general higher than the samples discussed by Robinson (1997), resulting in hydrogen impoverished kerogens. A second reason is the difference in organic composition, where the Eagle Ford Shale is enriched in kerogen with higher hydrogen content. Despite that, roof mudstones still are promising considering their TOC and S2 values and show potential as a source rock for shale gas or oil play according to standard criteria. The Westphalian coal deposits have been studied intensively the last two decades in terms of coal bed methane (Dreesen, 1993; Wenselaers et al., 1996; Langenaeker, 2000; Van Tongeren et al., 2000, 2001; Ferket \& Laenen, 2008). The presence of kerogen type II and an oil window maturity of the Hechter-Hoef roof mudstones indicate the capability of producing high-molecular-weight hydrocarbons. However, it should be noted that even the coal seams have a significant oil generation potential aside from the well-established gas generation potential, being characterized by higher average HI values than the shales (Littke et al., 1989; Scheidt \& Littke, 1989; Jasper et al., 2009). Nevertheless, the roof shales can add significantly to the total hydrocarbon potential of the Westphalian coal-bearing sequence.

\section{Conclusions}

This paper presents a study of the Westphalian roof mudstones in the Campine Basin (NE Belgium). The key objectives were to examine their potential as a source rock or shale play, the kind of hydrocarbons than can be generated and which parameters and factors control the hydrocarbon potential of these deposits.

An evaluation of TOC, S2 and Hydrogen Index indicates that these deposits do show hydrocarbon potential. The presence of kerogen type II in the sediment implies that these roof shales are capable of producing condensates and heavy hydrocarbons, in contrast to the gas-prone coal seams. It has also been found that a clear distinction in source rock potential can be made between the different stratigraphic units and palaeoenvironments, as defined by Paproth et al. (1996). Flood plain deposits have the highest hydrocarbon potential, followed by the euryhaline and fresh water environments. Based on TOC and S2 Westphalian A shales have a better hydrocarbon potential than Westphalian B deposits, with their higher content of Type II kerogen.

The observations suggest that the difference in kerogen content between the palaeoenvironments cannot clarify their differences in hydrocarbon potential. Although being the most enriched in kerogen type II, the euryhaline environment has not the highest hydrocarbon potential. Sedimentation rate, preservation during deposition and burial of organic matter also play a crucial role. In summary, dominance in organic matter of lake-origin or high sedimentation rates and preservation of organic matter after burial are regarded as positive factors. Environments with these characteristics occur more frequent in Westphalian A. In other words, the palaeogeographic differences between the stratigraphic units, such as steepening of the delta plain slope, the subsequent 
decrease in wet environments and the proximity of the Variscan deformation front have a crucial impact on the hydrocarbon potential of particular sediments. It was concluded that the palaeogeographic context of the sedimentary environment is indicative for the hydrocarbon generation potential within their shale deposits.

\section{Acknowledgements}

We would like to thank the Geological Survey of Belgium for the access to the archives and provide us the data. We are also grateful to our colleagues at CIM and LEK (RWTH Aachen) for their technical expertise. This paper also benefited from the review and the comments of Prof. Per Pedersen (University of Calgary) and Dr. Maartje Houben (Universiteit Utrecht) and the editorial handling of Dr. Annick Anceau. Wim Vandewijngaerde is a Ph.D. Candidate at the KU Leuven and is financially supported by a research grant of IWT, Flanders, Belgium.

\section{References}

Andrews, I.J., 2013. The Carboniferous Bowland Shale Gas Study: geology and resource estimation. British Geological Survey for Department of Energy and Climate Change, London, $56 \mathrm{p}$.

Besly, B.M., Burley, S.D. \& Turner, P., 1993. The late Carboniferous "Barren Red Bed" play of the Silver Pit area, Southern North Sea. In Parker, J.R. (ed.), Petroleum Geology of Northwest Europe: Proceedings of the $4^{\text {th }}$ conference. The Geological Society, London, 727-740.

Bertier, P., Swennen, R., Lagrou, D., Laenen, B. \& Kemps, R., 2008. Palaeo-climate controlled diagenesis of the Westphalian C \& D fluvial sandstones in the Campine Basin (north-east Belgium). Sedimentology, 55, 1375-1417.

Bouckaert, J. \& Dusar, M., 1987. Arguments géophysiques pour une tectonique cassante en Campine (Belgique), active au Paléozoique supérieur et réactive depuis le Jurassique supérieur. Annales de la Société Géologique du Nord, 106, 201-208.

Charpentier, R.R. \& Cook, T.A., 2011. USGS Methodology for Assessing Continuous Petroleum Resources. U.S. Geological Survey OpenFile Report, 2011-1167.

Collinson, J.D., 1988. Controls on Namurian sedimentation in the Central Province basins of northern England. In Besly, B.M. \& Kelling, G. (eds), Sedimentation in a synorogenic basin complex: The Upper Carboniferous of Northwest Europe. Blackie, Glasgow, 85-101.

Conford, C., Gardner, P. \& Burgess, C., 1998. Geochemical truths in large data sets: I. Geochemical screening data. Organic Geochemistry, 29/1-3, 519-530.

Delmer, A., 1952. La sédimentation cyclique et notamment la sédimentation houillère considérée comme un phénomène d'oscillations de relaxation autoentretenues. Compte rendu : Troisième congrès pour l'avancement des études de stratigraphie et de géologie du Carbonifère, Heerlen 1951, 1, 135-139.

Delmer, A., Dusar, M. \& Delcambre B., 2001. Upper Carboniferous lithostratigraphic units (Belgium). Geologica Belgica, 4/1-2, 95-103.

Dembicki Jr., H., 2009. Three common source rock evaluation errors made by geologists during prospect or play appraisals. AAPG Bulletin, 93/3, 341-356.

Ding, W., Zhu, D., Cai, J., Gong, M. \& Chen, F., 2013. Analysis of the developmental characteristics and major regulating factors of fractures in marine-continental transitional shale-gas reservoirs: A case study of the Carboniferous-Permian strata in the southeastern Ordos Basin, central China. Marine and Petroleum Geology, 45, 121133.

Dreesen, R., 1993. Seam thickness and geological hazards forecasting in deep coal mining: a feasibility study from the Campine Collieries (N-Belgium). Bulletin de la Société Belge de Géologie, $101,209-254$

Durand, B. \& Espitalié, J., 1973. Evolution de la matière organique au cours de l'enfouissement des sédiments. Comptes Rendus de l'Académie des Sciences Paris, 276, 2253-2256.

Dusar, M., 1989. The Westphalian C in the Campine Basin: coal content influenced by tectonics. Annales de la Société Géologique de Belgique, 112, 248-249.

Dusar, M., 2006. Namurian. In Dejonghe, L. (ed.), Current status of chronostratigraphic units named from Belgium and adjacent areas. Geologica Belgica, 9/1-2, 163-175.
Dusar, M., Bless, M.J.M., Burger, K., Demaret, M., Hardy, M., Langenaeker, V., Fan, L.S., Paproth, E., Piérart, P., Somers, Y., Streel, M. \& Wouters, L., 1998. De steenkoolverkenningsboring HechtelHoef (Boring 174 van het Kempisch Bekken). Geological Survey of Belgium Professional Paper, 286, 1-129.

Dusar, M., Langenaeker, V. \& Wouters, L., 2001. Permian - Triassic Jurassic lithostratigraphic units in the Campine Basin and the Roer Valley Graben (NE Belgium). Geologica Belgica, 4, 107-112.

Espitalié, J., Laporte, J.L., Madec, M., Marquis, F., Leplat, P., Paulet, J. \& Boutefeu, A., 1977. Méthode rapide de caractérisation des roches mères de leur potentiel pétrolier et de leur degré d'évolution. Revue de l'Institut Français du Pétrole, 32/1, 23-42.

Espitalié, J., Madec, M. \& Tissot, B., 1980. Role of mineral matrix in kerogen pyrolysis: Influence on petroleum generation and migration. AAPG Bulletin, 64, 59-66.

Ferket, H. \& Laenen, B., 2008. Een methode voor het berekenen van het methaangehalte van steenkoollagen. Studie uitgevoerd in opdracht van ALBON. VITO-rapport 2008/MAT/R/102, Mol (Belgium), 49 p.

Gasparik, M., Ghanizadeh, A., Bertier, P., Glensterblum, Y., Bouw, S. \& Kroos, B.M., 2012. High-pressure methane sorption isotherms of black shales from The Netherlands. Energy \& Fuels, 26/8, 49955004

Gradstein, F.M., Ogg, J.G., Schmitz, M.D. \& Ogg G.M., 2012. The geologic time scale 2012. Elsevier, Oxford, 1144 p.

Guo, H., Jia, W., Peng, P., Lei, Y., Luo, X., Cheng, M., Wang, X., Zhang, L. \& Jiang, C., 2014. The composition and its impact on the methane sorption of lacustrine shales from the Upper Triassic Yanchang Formation, Ordos Basin, China. Marine and Petroleum Geology, 57, 509-520.

Heckel, Ph.H., 1994. Evaluation of evidence for glacio-eustatic control over marine Pennsylvanian cyclothems in North America and consideration of possible tectonic effects. S.E.P.M. Concepts in Sedimentology and Paleontology, 4, 65-87.

Jasper, K., Krooss, B.M., Flajs, G., Hartkopf-Fröder, Chr. \& Littke, R., 2009. Characteristics of type III kerogen in coal-bearing strata from the Pennsylvanian (Upper Carboniferous) in the Ruhr Basin, Western Germany: Comparison of coals, dispersed organic matter, kerogen concentrates and coal-mineral textures. International Journal of Coal Geology, 80, 1-19.

Ji, W., Song, Y., Jiang, Z., Wang, X., Bai, Y. \& Xing, J., 2014. Geological controls and estimation algorithms of lacustrine shale gas adsorption capacity: A case study of the Triassic strata in the southeastern Ordos Basin, China. International Journal of Coal Geology, 134-135, 6173.

Katz, B.J., 1983. Limitations of Rock-Eval pyrolysis for typing organic matter. Organic Geochemistry, 4, 195-199.

Kombrink, H., Leever, K.A., van Wees, D.-D., van Bergen, F., David, P. \& Wong, T.E., 2008. Late Carboniferous foreland basin formation and Early Carboniferous stretching in Northwestern Europe: inferences from quantitative subsidence analyses in the Netherlands. Basin Research, 20, 377-395.

Kosters, M. \& Donselaar, M.E., 2003. Syn-sedimentary faulting and the formation of localized reservoir sands: Carboniferous examples from the Campine Basin, Belgium and the Dutch offshore. Petroleum Geoscience, 9, 309-319.

Langenaeker, V., 1992. Coalification maps for the Westphalian of the Campine Coal Basin. Geological Survey of Belgium Professional Paper, 256, 1-34.

Langenaeker, V., 2000. The Campine Basin: stratigraphy, structural geology, coalification and hydrocarbon potential for the Devonian to Jurassic. Aardkundige Mededelingen, 10, 1-142.

Langenaeker, V. \& Dusar, M., 1992. Subsurface facies analysis of the Namurian and earliest Westphalian in the western part of the Campine Basin (N Belgium). Geologie en Mijnbouw, 71, 161-172.

Langford, F.F. \& Blanc-Valleron, M.-M., 1990. Interpreting Rock-Eval Pyrolysis data using graphs of pyrolizable hydrocarbons vs. total organic carbon. AAPG Bulletin, 74/6, 799-804.

Littke, R., Horsefield, B. \& Leythaeuser, D., 1989. Hydrocarbon distribution in coals and dispersed organic matter of different maceral compositions and maturities. Geologische Rundschau, 78, 391-410.

Liu, B., Wan, L., Mao, F., Liu, J., Lü, M. \& Wang, Y., 2015. Hydrocarbon potential of Upper Cretaceous marine source rocks in the Termit Basin, Niger. Journal of Petroleum Geology, 38/2, 157-176.

Lorenzi, G., Bossiroy, D. \& Dreesen, R., 1992. Les minéraux argileux au service des corrélations stratigraphiques des formations houillères du Carbonifère. Rapport EU 14024 FR. Contrat 7220-AF/206, Luxembourg, $164 \mathrm{p}$.

Manning, R.A., 2014. The shale revolution and the new geopolitics of energy. Atlantic Council, http://www.atlanticcouncil.org/ publications/reports/the-shale-revolution-and-the-new-geopoliticsof-energy. 
McCarthy, K., Rojas, K., Niemann, M., Palmowski, D., Peters, K. \& Stankiewicz, A., 2011. Basic petroleum geochemistry for source rock evaluation. Oil Field Review, 23/2, 32-43.

McCartney, J.T. \& Teichmüller, M., 1972. Classification of coals according to degree of coalification by reflectance of the vitrinite components. Fuel, 51, 64-68.

McCartney, J.T. \& Teichmüller, M., 1974. Classification of coals according to degree of coalification by reflectance of the vitrinite components: a clarification. Fuel, 53, 63.

Nyhuis, C.J., Rippen, D. \& Denayer, J., 2014. Facies characterisation of organic-rich mudstones from the Chokier Formation (lower Namurian), south Belgium. Geologica Belgica, 17/3-4, 311-322.

Paltsev, S., Jacoby, H.D., Reilly, J.M., Ejaz, Q.J., Morris, J., O’Sullivan, F., Rausch, S., Winchester, N. \& Kragha, O., 2011. The future of U.S. natural gas production, use, and trade. Energy Policy, 39/9, 5309-5321.

Paproth, E., Dusar, M., Verkaeren, P. \& Bless, M.J.M., 1996. Stratigraphy and cyclic nature of lower Westphalian deposits in the boreholes KB174 and KB206 in the Belgian Campine. Annales de la Société Géologique de Belgique, 117/1, 169-189.

Patijn, R.J.H. \& Kimpe, W.F.M., 1961. De kaart van het Carboonoppervlak, de profielen en de kaart van het dekterrein van het zuid-Limburgse mijngebied en Staatsmijn Beatrix en omgeving. Mededelingen Geologische Stichting, 44, 5-12.

Peters, K.E. \& Cassa, M.R., 1994. Applied source rock geochemistry. In Magoon, L.B. \& Down, W.G. (eds), The petroleum system - from source to trap. AAPG Memoir, 60, 93-117.

Read, W.A.B, 1991. The Millstone Grit (Namurian) of the southern Pennines viewed in the light of eustatically controlled sequence stratigraphy. Geological Journal, 26, 157-165.

Robinson, C.R., 1997. Hydrocarbon source rock variability within the Austin Chalk and Eagle Ford Shale (Upper Cretaceous), East Texas, U.S.A. International Journal of Coal Geology, 34, 287-305.

Ross, D.J.K. \& Bustin, M., 2009. The importance of shale composition and pore structure upon gas storage potential of shale gas reservoirs. Marine and Petroleum Geology, 26, 916-927.

Sachsenhofer, R.F. \& Koltun, Y.V., 2012. Black shales in Ukraine: A review. Marine and Petroleum Geology, 31, 125-136.

Scheidt, G. \& Littke, R., 1989. Comparative organic petrology of interlayed sandstones, siltstones, mudstones and coals in the Upper Carboniferous Ruhr basin, Northwest-Germany, and their thermal history and methane generation. Geologische Rundschau, 78, 375-390.

Smith, N., Turner, P. \& Williams, G., 2010. UK data and analysis for shale gas prospectivity. In Vining, B.A. \& Pickering, S.C. (eds), Petroleum Geology: From Mature Basins to New Frontiers - Proceedings of the $7^{\text {th }}$ Petroleum Geology Conference. The Geological Society, London, 7, 1087-1098.

Söderbergh, B., Jakobsson, K. \& Aleklett, K., 2009. European energy security: The future of Norwegian natural gas production. Energy Policy, 37, 5037-5055.

Söderbergh, B., Jakobsson, K. \& Aleklett, K., 2010. European energy security: An analysis of future Russian natural gas production and exports. Energy Policy, 38, 7827-7843.

Tang, X., Zhang, J., Wang, X., Yu, B., Xiong, J., Yang, Y., Wang, L. \& Yang, C., 2014. Shale characteristics in the southeastern Ordos Basin, China: Implications for hydrocarbon accumulation conditions and the potential of continental shales. International Journal of Coal Geology, 128, 32-46.

Tissot, B., Durand, B., Espitalie, J. \& Combaz, A., 1974. Influence of the nature and diagenesis of organic matter in the formation of petroleum. AAPG Bulletin, 58, 499-506.

Uffman, A.K., Littke, R. \& Rippen, D., 2012. Mineralogy and geochemistry of Mississippian and Lower Pennsylvanian Black Shales at the Northern Margin of the Variscan Mountain Belt (Germany and Belgium). International Journal of Coal Geology, 103, 92-108.

Van Buggenum, J.M. \& den Hartog Jager, D.G., 2007. Silesian. In Wong, Th.E., Batjes, D.A.J. \& de Jager, J. (eds), Geology of the Netherlands. Royal Netherlands Academy of Arts and Sciences, Amsterdam, 43-62.

Van Keer, I., Muchez, P. \& Viaene, W., 1998a. Clay mineralogical variations and evolutions in sandstone sequences near a coal seam and shales in the Westphalian of the Campine Basin (NE Belgium). Clay Minerals, 33, 159-169.

Van Keer, I., Ondrak, R., Muchez, Ph., Bayer, U., Dusar, M. \& Viaene, W., 1998b. Burial history and thermal evolution of Westphalian coal-bearing strata in the Campine Basin (NE Belgium). Geologie en Mijnbouw, 76, 301-310.

Van Krevelen, D.W., 1950. Graphical-statistical method for the study of structure and reaction processes of coal. Fuel, 29, 269-284.

Van Tongeren, P.C.H. \& Laenen, B., 2001. Coalbed methane potential of the Campine Basin (N. Belgium) and related $\mathrm{CO}_{2}$-sequestration possibilities. Study ordered by NITG-TNO. VITO report 2001/ ETE/R/042, Mol (Belgium), 39 p.
Van Tongeren, P.C.H., Laenen, B. \& Dreesen, R., 2000. Hetkoolbedmethaan potentieel in Vlaanderen en de mogelijkheden tot geologische opslag van $\mathrm{CO}_{2}$ in relatie tot de winning van deze gasreserves. Een préhaalbaarheidsstudie t.b.v. de Administratie Natuurlijke Rijkdommen en Energie, VITO-rapport 2000/ETE/R/028, Mol (Belgium), 100 p.

Vandenberghe, N., Dusar, M., Laga, P. \& Bouckaert, J., 1988. The Meer well in North Belgium. Mémoires pour servir à l'Explication des Cartes Géologiques et Minières de la Belgique, 25, 23 p.

Vandewijngaerde, W., Nzekwe, O., Piessens, K. \& Dusar, M., 2013. The potential of organic rich roof shales in coal sequences: reevaluation of Westphalian samples in well KB174, Campine Basin, Belgium. Documenta Geonica, 2013/1, 171-176.

Wang, M., Wilkins, R.W.T., Song, G., Zhang, L., Xu, X., Li, Z. \& Chen, G., 2015. Geochemical and geological characteristics of the Es $3^{\mathrm{L}}$ lacustrine shale in the Bonan Sag, Bohai Bay Basin, China. International Journal of Coal Geology, 138, 16-29.

Weijermars, R., 2013. Economic appraisal of shale gas plays in Continental Europe. Applied Energy, 106, 100-115.

Welkenhuysen, K., Piessens, K., Baele, J.-M., Laenen, B. \& Dusar, M., 2011. $\mathrm{CO}_{2}$ storage opportunities in Belgium. Energy Procedia, 4, 4913-4920.

Wenselaers, P., Dusar, M. \& Van Tongeren, P.C.H., 1996. Steenkoollaag methaangaswinning in het Kempisch kolenbekken, "Het proefproject te Peer". Ministerie van de Vlaamse Gemeenschap, afdeling Natuurlijke Rijkdommen en Energie.

Yang, Y., Liang, C., Zhang, J., Jiang, Z. \& Tang, X., 2015. A development model of lacustrine shale gas genesis: A case from T3y 7 shale in the Ordos Basin, China. Journal of Natural Gas Science and Engineering, 22, 395-405.

Ziegler, P.A., 1982. Geological Atlas of Western and Central Europe Elsevier, Amsterdam, 130 p.

Ziegler, P.A., 1989. Evolution of Laurussia. Kluwer, Dordrecht, 100 p.
Manuscript received 23.10.2015, accepted in revised form 22.05.2016, available on line 29.07.2016 